\title{
Hyperreality of Law Between Hoax and Enforcement of Law no. 19 Year 2016: an Actualization of Technology Shift Law Perspective
}

\author{
Musa Darwin Pane \\ Faculty of Law \\ Universitas Komputer Indonesia, \\ Bandung, Indonesia \\ musa@email.unikom.ac.id
}

\begin{abstract}
The value of a reality existence is lost when fake news (hoax) is spread to all parts of law in Indonesia. The worst part is that as a result of this both law, technology and perception on the truth are simulated in a distortion (manipulation). It is to this condition that Jean Baudrillard label as hyperreality. The advancement of a media hyperreality cannot be separated from the development of media technology referred to as simulation technology. To support this study, the author uses the juridical normative approach, by analysing the problems through the legal norms within the code of laws, as an effort to actualize the building of an equitable legal security However, the primary highlight in the context of technology shift law is directed on how the law perspective considers the truth from fake news (hoax). Article 28 paragraph (1) of Law No. 16 Year 2016 have normatively protected people from hoax spreader, yet the law interpretation says differently, that the words "fake and "misleading are two different things. In the phrase "spreading fake news, what is specified is the action, and in the word "misleading what is specified is the result. The hoax phenomenon which grows and is made bigger in media hyperreality has now been a fairly complicated issues and its distribution is no longer unstoppable in Indonesia. Via social media in the Internet, the hoax phenomenon becomes highly confusing. So how, then, the law can judge it, an give an interpretation, and cange the condition to a valuable truth.
\end{abstract}

Keywords - Hoax; Bill Of Act No. 16 Year 2016 on Electronic Information and Transaction, Hyperreality of Law; Technology Shift Law. Keyword : Crimminal Law, Crime of Simulacra, Law Reform.

\section{INTRODUCTION}

The rapid development of information technology, accompanying all aspects of life and human needs, coincides with the discovery and development of knowledge in the field of information and communication. With the development of information technology, communication technology is growing rapidly [1]. this has an effect on the reform of criminal law, one of the factors that is the cause of change is the development of information technology that demands human activities to run quickly, transparently and without borders [2], so that crime can now be done without the need for the perpetrator and victim to be in the same location, or the perpetrator and victim do not have to have contact with each other [3].

This brief paper aims to introduce the hoax phenomenon in a scale far more affordable to hyperreality world, or postmodernism world. This is because either consciously or inconsciously the hoax and hyperreality phenomena are two complementary phenomena, providing a support to work each other for the sole purpose of falsehood.[4]

This study is completely new for no one has ever discussed it in the law science. It is possible that I am the first one to introduce this study. Yet, it is also possible that I am the n-th person to introduce this study. However, in the forms of a book, a journal, or an article or paper, this study is highly rarely discussed. My interest in studying this issue is that I wish to make it a basis for developing the law science in contemporary or post-modernism era. By this journal, the author intends to question the reality existence of the criminal law reformation, and how the existence of the positive criminal law in Indonesia (KUHP) is able to solve the problematics of simulacra in Indonesia.

\section{METHOD}

The research method used for this study is a method of normative juridical, which was done by analysing through the legal norms within the code of laws in Indonesia. This study is a part of doctrinal law study, as it studies the legal doctrines and the principles on the book as they are on the court precedents.

The typology of the study is descriptive analysis and the goal is to describe, to inventory and to analyse the concrete conditions about the legal development in regards to the crime of simulacra in the Indonesian criminal law. The secondary data used in the research were gathered from the primary sources in the form of legal codes. The data will be analysed by examining them to the criminal codes in Indonesia. 


\section{RESULT AND DISCUSSION}

\section{A. Law Hallucination and Hoax}

Jean Baudrillard asserts tahat theaseu and abundance of media, signs, and symbols has sobombarded our culture that "reality itself, as something separable from signs of it...vanished in the information-saturated, media-dominated contemporary world" (1018). Photography, mass production, television, and advertising have shaped and alteredauthentic experience to the point that "reality" is recognized only when it is re-producedin simulation. Truth and reality are mediated and interpreted to an extent that culture canno longer distinguish reality from fantasy. Baudrillard terms this blurring of mediatedexperience and reality "hyper-reality. [5] Hyperality is where physically real people meet virtual people who may, using technique described by Ahuja and sull, be projection of real people. [6]

Hyperreality is a condition where falsehood blends with authenticity, they are mixed (unification of cells and particles), facts coalesce with manipulations (fuse), signs melt with reality, lies combine with truth. Social media are frequently used as a platform to manipulate reality, i.e. a reality which seems real, while actually everything is just an imagery hallucination created through electronic technology. To sum it up, the current media hyperreality presents a condition within which everything is thought of as more real than the reality itself; falsehood is deemed as truer than the truth; issues are trusted better than information; and rumor is viewed as truer than the truth.

The hoax phenomenon which grows and is nurtured in media hyperreality has been fairly complicated issue in Indonesia. This is because via social media in the Internet, the hoax phenomenon becomes completely confusing. I assume that the condition of this hyperreality makes the recent modern society exaggerating their consumption of something whose essence is unclear. Most of this community consume not because of their economic need, rather due to the influence of models of simulation which leads to the different people's lifestyle. They become more concerned with the lifestyle and values they uphold.

Industry dominates many aspects of life. This industry produces a huge number of products, ranging from primary to secondary to even tertiary needs. Being equipped with semiotic and simulation powers make the product distribution and advertisement more aggressive. It is even more aggressive as the information technology allows the manufacturers to obtain information on what kind of people they are dealing with, and the customers obtain information on their needs which actually they do not need, yet they desire. The assumptions formed in human thought and this desire make human can never be freed from this hyperreality condition. This is actually the real hoax.

This phenomenon works thanks to the hoax makers skills in blending facts and manipulation. Some social media constitute the most-used platform to spread hoax, including Facebook, Twitter, and WhatsApp. In the rapid flow of information, every indidual can move freely to determine their own perception. It is as if reality has died, what remains is perception. This perception then appears more real than the reality. Using the perception which has been indoctrinized by the hoax makers, the information receiver will usually narrow down their perspective by inclining to only "want to read and believe what they want to believe. It is under such condition that Jeand Baudrilard calls as "real with not reality, [7] or "authentic falsehood in Umberto Ecos term.[8] Hoax has become a global problem unsettling and threatening the unity of nations, hence each countries designs and issues regulation in order to penalize the ones who make or spread fake news or hoax. The sanctions given are vary between a country and another. [9]

Literally, hoax is defined as false news which are made as if they are true, thus they can lead public opinion to apparently perceive that the hoax is true. If we relate hoax to EIT Law, hoax has been governed in article 28(1) of Law No. 11 Year 2008 on EIT. It is stated that: Anyone deliberately and without any right spreads fake and misleading news which result in losses to customers in Electronic Transactions".

In this Article 28(1) the word "fake" and "misleading" have different meanings, where the definition of "fake" is an action wherein the information spread in the form of either news or other information is the incorrect one and the word "misleading is the impact resulting from the action of spreading the fake news.

For example, someone spreads news wherein it is said that someone is a part of a terrorist network which misleading news has an impact in the form others judging the person in the news as a terorist based on thee hoax, yet in reality this person is not a part of any terrorist network. In order to interpret and apply at the same time this Article 28(1) of EIT Law, all elements stated in this article should be first met:

1. Anyone: this anyone means everyone who spreads the hoax.

2. Deliberately and without right: means that this "Deliberately" whether or not there is malicious intention in comitting the action. It is also important to note whether the spreader has right or not to spread the fake and misleading news. The definition of "fake" and "misleading" is different in the perspective of law. Therefore, it is important to note whether the spread information contains the fake element in which case the news contain incorrectness which further lead others/the public to have wrong perspective to certain information. If these elements are met, then the perpetrator needs to be punished.

3. Which result in losses to customers in electronic transactions: to fulfill this element, it is important to note whether the information results in losses to customers, in this case it can be an individual, a group, or a company. 
These elements in Article 28(1) of EIT Law use a cumulative system as characterized by the use of word "and." This cumulative system means all of these elements should be fulfilled first before this article can be enforced. These are hoax, hyperreality and EIT Law at a glance. Basically, it will be hard for the law to deal with the hoax phenomenon when the normative regulations on it are not fulfilled. However, it is possible to deal with the hyperreality condition when every fake news can be classified as hoax, which work in the name of the truth, which justifies falsehood.

\section{CONCLUSION}

After knowing the danger of hoax (spreading falsehood, lies) with media hyperreality phenomenon, it is now clear that the phenomenon above is one in the form of organized lies and these organized lies can beat unorganized truths. Apparently, the government quickly responds to this hoax phenomenon. As a form of legal sanction to this hoax crime, the government has revised Law on EIT and now it has been enacted as Law No 19 Year 2016 on amendment of Law No. 11 Year 2008 concerning Electronic Information and Transaction. It needs dissemination to the society to make more cautious and wise in interacting with cyber world.

\section{REFERENCES}

[1]. M. Afif Hasbullah, Hoax In Legal Perspective and Literacy Education in Digital Era, International Seminar and Call For Paper, Darul Ulum Islamic University Of Lamongan, 2017.

[2]. Didik M. Arief Mansur \& Elistaris Gultom, Cyber Law : Aspek Hukum Teknologi Informasi, Refika Aditama, Bandung, 2005.

[3]. Nyaman Gibson Miralis, Why is Cyber Crime Regarded as a Borderless Crime?, NGM Defence Lawyers and Advisor, Sydney, 2016.

[4]. Eco, Umberto, Travel-in- Hyperreality, Picador, London, 1987.

[5]. John Lechte, 50 Filsuf Kontemporer, Yogyakarta: Penerbit Kanisius, 2001.

[6]. J. Baudirilliard, The Hyper-realism of Simulation art in Theory 1900-1990: an Antology of Changing Ideas, (eds). Charles Horison \& Paul Wood, Oxford : Balckwell Publisher Ltd, 1992.

[7]. Jhon Tiffi \& Noby Yoshi Tershima, Hyperality : Paradigm For the Third Millenium, Phsycology Perss, 2001.

[8]. Jean Baudrillard: From Hyperreality to Disappearance: Uncollected Interviews, Edinburgh University Press, 2015.

[9]. Almira Ousmanova, Fake At Stake: Semiotics Ano The Problem of Authenticity, Journal Problemos Vol. 66 (1), European Humanities University, Department of Culturology, 2004. 